\title{
EDUCAÇÃO TEATRAL E TRANSDISCIPLINARIDADE: RELAÇÕES DE ENSINO-APRENDIZAGEM NA TEIA CURRICULAR DA ESCOLA VILA
}

\section{RESUMO}

Esse texto visa debater sobre o território de ensino-aprendizagem propiciado pelas aulas de teatro na teia transdisciplinar da Escola Vila, em Fortaleza/CE. Escola que trabalha em um contexto ecoformativo e plural, onde os estudantes têm a experiência de estudar em um ambiente sensível que prima pelo ensino das artes em suas especificidades. Trata-se, de um trabalho que estuda o teatro enquanto componente curricular formativo, no qual estudantes e professores podem desenvolver habilidades teatrais formativas no campo das artes e da educação.

PALAVRAS-CHAVE: Transdisciplinaridade; Ecoformação; Educação teatral; Escola Vila; Teia curricular.

\section{ABSTRACT}

This text aims to discuss the teaching-learning area provided by the theater classes in the transdisciplinary network of "Escola Vila", in Fortaleza / CE. School that works in an ecoformative and plural context, where students have the experience of studying in a sensitive environment that excels for the teaching of the arts in their specifics. It is a work that studies theater as a formative curricular component which students and teachers can develop theatrical skills in the arts and education.

KEY WORDS: Transdisciplinarity; Ecoformation; Theatrical Education; Escola Vila; Curricular Network.

A teia curricular da escola Vila trabalha com um currículo em constante fluxo, onde tudo é interligado e os conteúdos são trabalhados de forma transdisciplinar. "Uma Teia é tecida linha a linha, ligando-se pontos em uma única trama. A proposta da Teia Curricular é não somente analisar, mas também relacionar, interligar, gerar sentidos e sínteses.” (LIMAVERDE, P., LIMAVERDE, F., p. 385, 2008). Essa transdisciplinaridade da teia curricular traz um trabalho latente com as artes, trabalhando a sensibilidade, as emoções e o cuidado com o corpo, colocando o artesanato, as artes plásticas, o teatro e a música dentro do currículo. 
Percebendo esse olhar da escola Vila para o sensível, o objetivo desse trabalho é relatar a experiência vivida nas aulas de teatro da Escola Vila, bem como debater sobre as possibilidades metodológicas de trabalhar o teatro como disciplina curricular com conteúdos próprios, avaliação, carga-horária e culminância.

Nas Aulas de teatro da Escola vila o propósito é desenvolver técnicas e métodos de abordar os conteúdos do teatro de maneira transdisciplinar enquanto território sensível, gerador de percepções e modos de compreensão dos códigos e das linguagens estéticas, sociais, ambientais e políticas, percebendo as implicações na construção do conhecimento dos alunos desde as aulas até as apresentações.

Na Escola Vila o teatro começa na educação infantil e vai até o fundamental II, focando o olhar nas aulas de teatro do Fundamental I, têm-se o intermédio entre o primeiro contato na educação infantil e o desenvolvimento técnico da apresentação de um espetáculo no fundamental II. Os alunos do fundamental I semanalmente vão à sala prática onde têm aulas de teatro e também de corpo-meditação, yoga, dança circular, biodança-. Nas aulas de teatro os conteúdos são divididos por bimestre e ao final de cada bimestre acontece uma avaliação acompanhada ou não da apresentação de um espetáculo.

É previsto no currículo do fundamental I que o aluno estude em teatro aspectos de dramaturgia, espaço, cenário, construção de personagens, montagem de espetáculos, formação de plateia, uso do som no teatro, tipos de teatro e estudo do movimento. Esses conteúdos são abordados metodologicamente com base nos pesquisadores Stanislavski (1997), Viola Spolin(2007) e Augusto Boal(2008), através de jogos teatrais, jogos dramáticos, improvisação, estudo de dramaturgia e apreciação cênica.

A avaliação ocorre durante uma aula inteira onde os alunos dispostos em círculo- nos primeiros anos- e em grupos- nos anos finais-, avaliam-se. É provocado um debate e os estudantes precisam decidir em comum acordo uma nota coletiva para cada aluno e também cada um, individualmente, deve pensar uma nota que serve como auto-avaliação, a professora também deve pensar uma nota baseada em critérios como assiduidade, prontidão, organização, 
responsabilidade, respeito e participação adequada nas situações individuais, de grande grupo e de mini grupo. Por fim, é feita uma média entre as notas e cada aluno recebe junto com a avaliação das outras disciplinas em uma ficha de acompanhamento individual produzida pela escola.

É comum vermos que o contato do aluno com a prática teatral na escola acontece de forma extracurricular, quando ocorre. Fato é que muitas escolas negligenciam o teatro enquanto componente curricular necessário à grade escolar, optando por um ensino cartesiano. Trabalhar teatro como disciplina é pensar o teatro como espaço gerador de conhecimento, de saberexperiência, aproveitando de sua natureza transdisciplinar para trabalhar os indivíduos dentro de suas especificidades.

O teatro trabalhado de maneira transdisciplinar ocupa um lugar de fruição e catarse que dá sentido à vida, colocando o aluno em um patamar de autoria e protagonismo e fornecendo ferramentas para uma relação de companheirismo, coletividade, respeito e cuidado com o outro.

Ter a oportunidade de pesquisar a educação teatral em uma escola que trabalha o teatro no currículo dentro de uma pedagogia autoral e pioneira no Brasil é difundir uma prática educacional que pode ser exemplo no Brasil e no mundo, alertando para as implicações positivas na vida dos alunos e revelando uma forma de construção de conhecimento qualitativa e que preza pela atuação social, ambiental e política.

\section{REFERÊNCIAS BIBLIOGRÁFICAS}

BOAL, A. Jogos para atores e não-atores. Rio de Janeiro: Civilização Brasileira, 2008. SPOLIN, Viola. Jogos teatrais na sala de aula: um manual para o professor. Perspectiva, 2007.

STANISLAVISKI, C. S. Manual do ator. São Paulo: Martins Fontes, 1997. 